\title{
ASSESSMENT OF UNTERRACED AND TERRACED FARMING SYSTEM ON LIVESTOCK DEVELOPMENT IN MID-HILLS OF NEPAL
}

\author{
Gopal Giri ${ }^{1}$, Dainik B. Nepali², Bhola S. Shrestha ${ }^{3}$
}

\section{ABSTRACT}

The unterraced farming (Pata) system which is being practiced in few districts of mid hills of Nepal was assessed in terms of livestock holding and livestock feed availability against the terraced farming system. Field study and household survey was conducted in Arghakhanchi (representing unterraced/Pata) and Tanahun (representing terraced) farming system by selecting 90 households (HHs) from each districts randomly. The study showed that there was only 1.89 Livestock Unit (LU)/HH in Arghakhanchi as compared to 2.64 LU/HH in Tanahun $(p<0.01)$. Dry matter (DM) output per hectare rainfed upland in Tanahun was 6.09 Metric Ton (MT) whereas it was only 3.82 MT in Arghakhanchi $(p<0.01)$. The farming system of Arghakhanchi has created livestock feed shortage, consequently has compelled farmers to raise least number of animals. Hence unterraced farming system of Arghakhanchi needs correction for better livelihood of people as well as improvement in environmental condition.

Keywords: crop, farming system, fodder trees, livestock, terraced farming, unterraced farming (Pata)

\section{INTRODUCTION}

\section{BACKGROUND}

Agriculture is the mainstay of Nepalese economy. It is a major source of livelihood of Nepalese people and about 65.6 percent of economically active populations are engaged in this sector (MOAC, 2010). The contribution of this sector in national Gross Domestic Product (GDP) is 31.1 percent (NPC, 2007).

The livestock sub sector review $(A D B, 2001)$ has concluded that livestock is a very important part of the agriculture and has a key role to play in the country's development and in poverty alleviation.

The raising of livestock is integrated with food crop production in the country, where crops provide feed and fodder, livestock provides meat, milk and milk products etc. for subsistence and as a source of cash income for the farmers. Livestock provides manure which is the major source of nutrients for crop production. Livestock also supply draught power to till the land and provide power for other agricultural operations such as threshing and transport (Tulachan et al 1999).

As $36 \%$ livestock feed is contributed by the crop by-products (Giri, 1990), the productivity of cereal crops is highly related with the supply of livestock feed. Farmers in most of the districts of mid-hill region of Nepal have been adopting

\footnotetext{
${ }^{1}$ Senior Livestock Development Officer, DLSO Baglung, Nepal. Email: glgiri@yahoo.com

${ }^{2}$ Professor, Department of LPM, IAAS, Rampur, Chitwan, Nepal. Email: dainik77@gmail.com

${ }^{3}$ Senior Scientist, Bovine Research Program, NARC, Khumaltar, Nepal. Email: bsshrestha@yahoo.com
} 
terrace farming system for the agriculture production where the plots are generally narrow, and flatness of them depends on slope of geography (Figure 2). But in contrast to this, few districts in the areas where farmers adopt large and unterraced (Pata) farming system, where terrace size is perceived as reflecting wealth and status (Acharya et al 2008). So that "Thulapate (person having large sized plots)" is common term in these districts which reflect the wealth and status of the farmers i.e. "Greater the plots size, higher the social status and wealth of farmer in the community". The farming system of this kind is prevalent in Arghakhanchi and other districts such as Palpa, Gulmi and so on where flat (leveled) and narrow terracing system is almost nonexistent (Figure 3). There is tradition of making bigger piece of land by assimilating adjoining land without considering the slopes. The size of single plot is found to be up to one hectare. The sloppiness of the plot depends on the geography ranging from $0^{\circ}$ to $60^{\circ}$. This system generally, in local area, is called Pata system. Due to the sloping nature of the land, there is heavy soil loss during the rainy season. The sloppiness of land in association with nutrient loss due to erosion and less tree cover around the land causes increased moisture evaporation and lessen the organic matter content in the soil. Reduced organic matter in the soil causes the decreased moisture retaining capacity of soil. Hence, both production and productivity of the crop has been declining as experienced by majority of the farmers in the district. The decreased production and productivity of cereal crops means less crops by-products and crop residue available to feed the livestock

The report published by Ministry of Agriculture and Cooperatives, Nepal (2008/09) clearly reflects that there is lower ruminant holding as well as lower productivity of major cereal crops in Arghakhanchi and other districts where such type of farming system is in practice as compared to districts where farmers adopt terraced farming system. The reduced livestock holding and decreased productivity of crops might be the result of unterraced (Pata) farming system and assessment of which is necessary against the terraced farming system that is most common in mid-hill region of country.

\section{OBJECTIVES}

To assess livestock holding, fodder tree density and dry matter production per unit rainfed upland for livestock feeding in two districts with different land use pattern i.e. unterraced (Pata) and terraced farming system.

\section{MATERIALS AND METHODS}

For the purpose of the study two districts namely Arghakhanchi representing unterraced (Pata) farming systems and Tanahun representing terraced farming system in mid hill region were selected. Both districts are in western development region of Nepal having almost similar climate, rainfall, weather and altitude on the basis of available recorded data except the difference being in farming system on rainfed upland.

3 Village Development Committees (VDCs) were purposively selected from each districts through randomization so that market has not any influence on productivity of agriculture and livestock and the farmers' livelihood was based 
solely on subsistence farming. Assistance from technicians of both District Agriculture Development Office (DADO) and District Livestock Service Office (DLSO) as well as leader farmers along with local political leaders in respective districts was taken for the study. The record of total HHs in the selected ward was obtained from respective VDC offices. One ward from each VDC and $30 \mathrm{HHs}$ from the selected ward were chosen by randomization techniques. Thus from each district 90 $\mathrm{HHs}$ were selected so that there were altogether $180 \mathrm{HHs}$ from two districts in the study. For randomization, the RAND, a random number generator of Microsoft Excel was used. The location of districts within the country is presented in Figure 1.

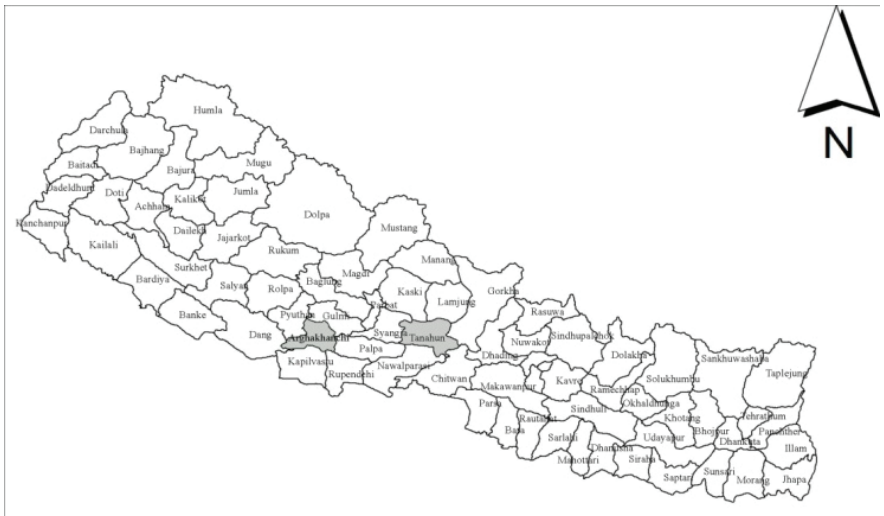

Figure 1: Map of Nepal showing location of study districts

Socioeconomic study was carried out for the selected HHs by semi structured questionnaire, interview and field survey. Together with these, the slope of rainfed upland for the selected HHs was estimated by measuring plot's breadth and riser's height in terraced land of Tanahun, while bamboo stick, string and stone were used for calculating slope in unterraced land (Pata) of Arghakhanchi. Following formulae were applied to estimate the degree of slope for different land.

Slope degree for terraced land

$$
\operatorname{Tan} \theta=\frac{\text { Height }}{\text { Breadth }}
$$

Slope degree for unterraced land

$$
\cos \theta=\frac{\text { Breadth }(\mathrm{b})}{\text { Hypoteneous }(\mathrm{h})}
$$

For the estimation of crop residue, the conversion factor suggested by Pande (1994) was used and the factor he has suggested for different crops is presented in Table 1. 
Table 1. Conversion factor for grain yield and by-product estimation in different crops

\begin{tabular}{|c|c|c|c|c|}
\hline Crop & By-products & $\begin{array}{l}\text { Ratio of } \\
\text { products }\end{array}$ & grain and by- & $\begin{array}{l}\text { Percent that can be used as livestock } \\
\text { feed }\end{array}$ \\
\hline \multirow[t]{2}{*}{ Rice } & Straw & & 1.72 & 80 \\
\hline & Rice polish & & 0.13 & 100 \\
\hline \multirow[t]{2}{*}{ Maize } & Stover & & 2.21 & 50 \\
\hline & Cob & & 0.13 & 80 \\
\hline \multirow[t]{2}{*}{ Wheat } & Straw & & 2.17 & 80 \\
\hline & Chuni & & 0.34 & 100 \\
\hline Millet & Straw & & 1.95 & 70 \\
\hline \multirow[t]{2}{*}{ Mustard } & Bhusa & & 0.7 & 60 \\
\hline & Cake & & 0.55 & 100 \\
\hline Pulses & Bhusa & & 0.4 & 90 \\
\hline
\end{tabular}

Pande (1994) also has considered $300 \mathrm{Kg}$ live weight of livestock is equivalent to one Livestock Unit (LU) in Nepalese condition. For estimation of LU, the average body weight for different categories of livestock were considered according to value presented in Table 2 . The average body weight of different categories of livestock was considered by thorough discussion with farmers and livestock service technicians.

Table 2. Tentative body weight of different categories of native livestock species in Nepalese condition

\begin{tabular}{|c|c|c|}
\hline S.N. & Livestock species & Tentative Body weight in Kilogram (Kg) \\
\hline \multirow[t]{5}{*}{1} & Buffalo: Adult Buffalo & 320 \\
\hline & Breeding Bull & 350 \\
\hline & Heifer & 200 \\
\hline & Male Calf & 50 \\
\hline & Female Calf & 50 \\
\hline \multirow[t]{5}{*}{2} & Adult Cattle & 250 \\
\hline & Breeding Bull and Oxen & 250 \\
\hline & Heifer & 100 \\
\hline & Male Calf & 40 \\
\hline & Female Calf & 40 \\
\hline \multirow[t]{3}{*}{3} & Adult Goat & 30 \\
\hline & Breeding/Castrated Buck & 30 \\
\hline & Male/Female Kid & 10 \\
\hline
\end{tabular}

For the study, the total area of land in Ropani was determined by asking question to family head. One Ropani land assumed to have an area of 508.5 square meters (Agriculture Diary, 2010). Hence one hectare land approximately contains 20 Ropani land and the conversions were made accordingly. The areas of each type of land were recorded by questionnaire and the slope of only rainfed upland was considered in both the districts.

Pariyar (1993) estimated that natural pastures of one hectare (ha) land at the altitude range of 800 to 1600 meter above sea level (masl) in Dhading district of 
Nepal can produce 0.79 Metric Ton (MT) dry matter in a year. Hence this value was taken as reference to estimate the dry matter output from the available terrace areas and uncultivable rainfed upland (Kharbari) in both the districts.

The crop yield was estimated according to the local estimation that is opted in the areas. The average crop yield was estimated by asking questions related to yield of crops over the past 2-3 years in terms of Muri, Pathi, Doko, Bhari. The yield obtained in this form was converted into Kilograms. Later the Kilogram was converted to Metric Ton (MT). The Kilograms in Muri, Pathi, Doko, Bhari was estimated by averaging all estimated value provided by different leader farmers.

Microsoft Excel, SPSS (version 18) and Minitab (version 13) was used for the data analysis and level was set as 0.05 . Data were subjected to normality test as and when necessary. Two sample T Test, one way and two way ANOVA, correlation analysis, Chi square test were performed where appropriate.

\section{RESULTS AND DISCUSSIONS}

\section{SELECTED VDCS, WARD NUMBER AND HOUSEHOLD FOR THE STUDY}

In Tanahun district, 3 VDCs i.e. Risti-1, Arunodaya-8 and Kinhun- 4 were selected whereas in Arghakhanchi district Nuwakot-3, Wangla-4 and Pali-8 were selected through RAND. Thirty HHs from each ward were selected by same techniques, so that there were $90 \mathrm{HHs}$ from each district. Out of total $90 \mathrm{HHs}$ in Tanahun, $33 \mathrm{HHs}$ were from Dalit, $18 \mathrm{HHs}$ from Janajati and $39 \mathrm{HHs}$ from Others ethnic group. Similarly in Arghakhanchi there were 22, 15 and $53 \mathrm{HHs}$ were from Dalit, Janajati and Others ethnic group respectively. Chi square test for equal proportion in two districts showed that there was no significant difference in ethnic composition between 2 districts $(P>0.05)$.

\section{LAND HOLDING SITUATION OF HHS BETWEEN STUDY DISTRICTS}

Out of total available land in Tanahun district, $74.2 \%$ land was rainfed upland, 19.7 $\%$ was rainfed lowland, $6.1 \%$ was irrigated lowland. Whereas in Arghakhanchi out of total available land $90.15 \%$ was Rainfed upland, $8 \%$ was rainfed lowland, $1.85 \%$ was irrigated lowland.

When only rainfed upland was considered, $84.7 \%$ rainfed upland was cultivable in Tanahun and only remaining $15.3 \%$ was unsuitable for cultivation which was used as Kharbari (uncultivable rainfed upland). But in Arghakhanchi out of total rainfed upland only $42 \%$ rainfed upland was cultivable and remaining $58 \%$ was used as Kharbari (uncultivable rainfed upland).

Farmers of Tanahun and Arghakhanchi had $8.03 \pm 6.73$ and $6.35 \pm 4.97$ Ropani cultivable Rainfed upland per $\mathrm{HH}$ respectively, which was not significant at $5 \%$ level. But when uncultivable rainfed upland (Kharbari) was considered, farmers of Tanahun had lesser uncultivable Kharbari holding (1.46 \pm 3.23 Ropani) as compared to farmers of Arghakhanchi (8.78 \pm 7.95 Ropani), the difference of which was 
significant at $1 \%$ level. In terms of total land holding/HH there was no significant difference $(\mathrm{p}>0.05)$ between the $\mathrm{HHs}$ of Tanahun $(0.639 \mathrm{ha} / \mathrm{HH})$ and Arghakhanchi (0.839 ha/HH).

The less Kharbari land holding in Tanahun was associated with the terraced farming system where farmers had brought almost all land into cultivation as much as possible. During the study period it was found that almost all land up to 70 degree slope in Tanahun districts was under cultivation by making narrow strip of terraces which were even less than a meter in width. But in contrast to Tanahun, farmers of Arghakhanchi were not using land having 60 degree and greater than this into cultivation and they have left such land as Kharbari (uncultivable rainfed upland). They had larger sloping unterraced plots of rainfed upland for cultivation.

The productivity of uncultivable rainfed upland (Kharbari) when brought into cultivation by terracing can yield more dry matter through crop by-products, increased terrace areas and increased fodder tree density. It insures not only to supply sufficient livestock feed but also adds in food security.

\section{LIVESTOCK HOLDING SITUATION}

In terms of livestock unit (LU) per HH, Tanahun district had greater LU $(2.64 \pm 1.62)$ than Arghakhanchi district $(1.89 \pm 1.21)$ which was significant at $1 \%$ level

The LU per HH among different study sites within the districts had no significant differences at $5 \%$ level. In Tanahun district, the LU per HH for Risti-1 was $2.45 \pm 1.4$, for Arunodaya-8 it was 2.28 \pm 1.98 and for Kinhun-4 the value was $3.19 \pm 1.30$. Similarly in Arghakhanchi district LU for Nuwakot-3 was $1.54 \pm 0.98$, Wangla-4 was $2.01 \pm 1.42$ and for Pali-8 the value was $2.11 \pm 1.17$. There was no significant difference in $\mathrm{LU}$ per $\mathrm{HH}$ among the study sites within the district; hence it further proves that there was more number of livestock where terraced farming system is in practice (Tanahun) as compared to areas where the terrace farming system is not in practice (Arghakhanchi).

The livestock holding per hectare rainfed upland in Tanahun district was $7.18 \pm 8.48$ LU where as in Arghakhanchi same land could hold only $3.26 \pm 3.58 \mathrm{LU}$, the difference was highly significant at $1 \%$ level. 


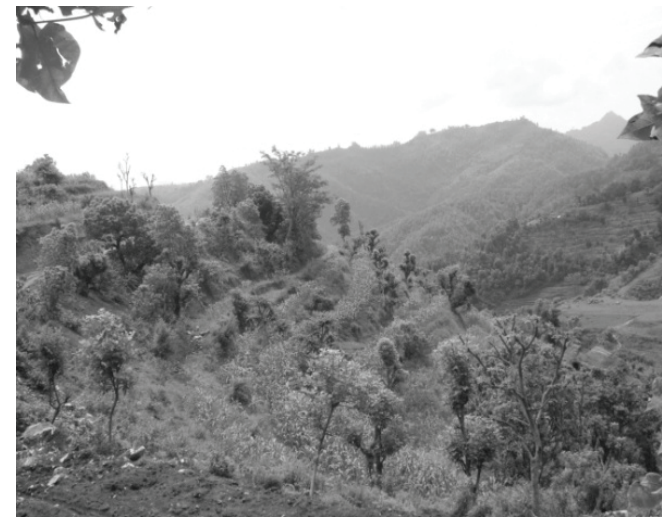

Figure 2. Maize in terraced farming system in Kinhu-4, Tanahun.

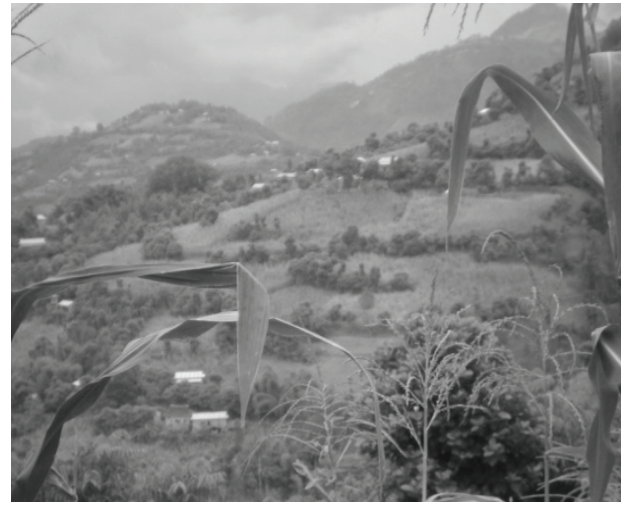

Figure 3. Maize in unterraced (Pata) farming system in Wagla-4, Arghakhanchi

\section{LIVESTOCK FEED AVAILABILITY}

\section{DM production from cultivable rainfed upland}

The same rainfed upland in Tanahun could produce $6.09 \pm 4.29$ MT dry matter/ha whereas in Arghakhanchi it could produce only $3.82 \pm 1.57$ (37.24 \% less than Tanahun) dry matter/ha rainfed upland. Hence due to high productivity of rainfed upland in terms of dry matter in Tanahun district there was more number of livestock as compared to the Arghakhanchi. Due to unterraced (Pata) farming system in Arghakhanchi, there were less terrace areas and less number of fodder trees which ultimately have resulted less dry matter production per unit rainfed upland. There was high correlation between LU and land holding specially with Rainfed upland $(\mathrm{P}<0.01)$, but there was no correlation between $\mathrm{LU}$ and lowland in both the districts. But high correlation exists between LU and uncultivable rainfed upland (Kharbari) in Arghakhanchi $(p<0.01)$ where as in Tanahun the correlation for the same was not significant ( $p>0.05)$.

Pande (1994) has mentioned that terrace risers and terraces can provide green grass up to 4 months period in Nepal. For this study, the productivity of terrace risers was considered to be $798 \mathrm{Kg} \mathrm{DM} / \mathrm{ha}$ (Pariyar, 1993). The average terrace area per hectare land in Tanahun was $4452 \pm 2068$ sq.m., whereas it was only $594 \pm 557$ sq.m. in Arghakhanchi so that the DM production from terraces in Tanahun was 352 $\mathrm{Kg} / \mathrm{ha}$ as compared to only $47 \mathrm{Kg} / \mathrm{ha}$ in Arghakhanchi and the difference was highly significant $(p<0.01)$.

The dry matter production from crop by-products from cultivable rainfed upland in Tanahun was $2.33 \pm 1.44 \mathrm{MT} /$ ha whereas in Arghakhanchi it was $2.46 \pm 1.24$, but this difference was not significant ( $p>0.05)$. Out of total dry matter production, terrace has contributed $3.37 \%$ in Tanahun, whereas its contribution in Arghakhanchi was only $0.58 \%$. Fodder tree in Tanahun has contributed $45.61 \%$ of total dry matter production, but its contribution in Arghakhanchi was only $36.03 \%$. The contribution of crop by-products from cultivable rainfed upland in Tanahun was $20.3 \%$ whereas its contribution in Arghakhanchi was $29.2 \%$. 


\section{Fodder tree status}

The number of fodder trees/ha land in Tanahun and Arghakhanchi was found to be $191 \pm 177$ and $81.6 \pm 54.2$ respectively. Due to higher number of fodder trees, total dry matter yield in Tanahun district was much higher as compared to yield in Arghakhanchi district. The mean dry matter yield from fodder tree/ha land in Tanahun and Arghakhanchi was found to be $3.42 \pm 3.42$ and $1.317 \pm 0.947 \mathrm{MT} / \mathrm{ha}$ respectively $(p<0.01)$. The study showed that the terraced farming system can accommodate more number of fodder trees per unit land as compared to unterraced (Pata) farming system without any negative consequences in crop yield. The dry matter from fodder trees was calculated on the basis of values given by Subba (1998), Upreti et al. (2006) and Amatya (1990).

\section{Demand and supply of DM requirement for livestock feeding in study districts}

The data presented in Table 3 shows that $29.16 \%$ of livestock feed in terms of dry matter was deficit in Tanahun district, whereas the feed deficit percentage in Arghakhanchi was further greater i.e. $39.15 \%$. The livestock feed deficit percentage in Tanahun was lesser than Arghakhanchi despite the greater number of livestock holding. Hence it could be said that livestock holding and feed availability for the livestock is better in the areas where terraced farming system is practiced as compared to areas where unterraced (Pata) farming system is in practice. Lower livestock feed availability means higher pressure in forest resources (off farm resources) for livestock feed. Hence it could be concluded that there was high pressure on forest in Arghakhanchi district as compared to Tanahun for fodder supply. This means that further deterioration of forest resources is inevitable if necessary measures are not taken in time in Arghakhanchi district.

Table 3. Demand and supply of DM requirement for livestock feeding in study districts

\begin{tabular}{lcc}
\hline Description & Tanahun & Arghakhanchi \\
\hline Mean Livestock Unit/ HH & $2.64 \pm 1.62$ & $1.89 \pm 1.21$ \\
Yearly requirement of DM (MT) & $5.28 \pm 3.24$ & $3.78 \pm 2.43$ \\
Yearly supply of DM (MT) & $3.74 \pm 3.50$ & $2.30 \pm 1.93$ \\
Deficit (MT) & 1.54 & 1.48 \\
Percentage deficit & 29.16 & 39.15 \\
\hline
\end{tabular}

\section{CROP PRODUCTIVITY}

Although there was high fodder tree density in Tanahun district, the productivity of cereal crops was not found significantly different from Arghakhanchi district except in maize. The productivity of maize in Arghakhanchi was found to be higher $(1.39 \pm 0.63 \mathrm{MT} / \mathrm{ha})$ than that of Tanahu district $(1.20 \pm 0.58 \mathrm{MT} / \mathrm{ha})$, which was significant at $5 \%$ level. It was found that farmers of Arghakhanchi were using urea fertilizer with high application rate i.e. $75.4 \pm 80.5 \mathrm{Kg} / \mathrm{ha}$ as compared to Tanahun where the rate was only $8.7 \pm 17.2 \mathrm{Kg} / \mathrm{ha}(\mathrm{p}<0.01)$. The increase in maize yield in Arghakhanchi could be the result of application of high rate of urea fertilizer.

\section{CORRELATION OF LIVESTOCK UNIT WITH RAINFED UPLAND}

There is high correlation of Livestock unit with rainfed upland in both the districts than other forms of land. When Kharbari land was considered, there was high 
correlation of Kharbari with Livestock unit in Arghakhanchi $(r=0.37, p<0.01)$, but it was not significant for Tanahun. For livestock feeding, farmers of Arghakhanchi are dependent on Kharbari land due to less terrace areas, lower number of fodder trees and lower crop by products resulting from lower crop productivity from the cultivable rainfed upland. For the case of Tanahun district, It is clear that farmers in the district get feeds for their livestock from more terrace areas, greater number of fodder trees and more crop by products resulting from more crop productivity from the rainfed upland. Hence farmers do not depend on Kharbari land in Tanahun district for livestock feeding and due to sufficient availability of feeds they have raised more numbers of livestock. The sloping land unlike in Arghakhanchi has been brought into cultivation by adopting terraced farming system to produce cereals.

\section{FOOD SECURITY SITUATION}

Most of the rainfed upland $(84.7 \%)$ in Tanahun was under cultivation due to terraced farming system, but its proportion in Arghakhanchi was only $42 \%$. The uncultivated upland (Kharbari) in Arghakhanchi district could be brought into cultivation for increased cereal production if terraced farming system is adopted.

When cultivable rainfed upland taken under consideration, $1.70 \mathrm{MT} / \mathrm{ha}$ raw grain had been produced in Arghakhnchi as compared to $1.65 \mathrm{MT} /$ ha in Tanahun $(\mathrm{p}<0.01)$. But to produce this quantity, farmers had used $75.4 \pm 80.5 \mathrm{Kg}$ urea fertilizer per ha in Arghakhanhci as compared to only $8.7 \pm 17.2 \mathrm{Kg}$ in Tanahun. When total available rainfed upland (both cultivable and Kharbari) was considered, the total grain production in Tanahun was $1.4 \mathrm{MT} /$ ha but its value for Arghakhanchi was only 0.7 MT/ha. In the same way farmers in Arghakhanchi have also lost 2.27 MT of dry matter (for livestock feeding) from unit hectare of rainfed upland when compared with Tanahun district. Hence there is greater opportunity to increase both grain and dry matter yield if terraced farming system is adopted in Arghakhanchi district.

During the study period the farmers were asked about how many months the grain would sufficient for $\mathrm{HH}$ feeding. The result showed that the grain production from rainfed upland had supported $5.5 \pm 3.45$ and $7.54 \pm 3.91$ month in Arghakhanchi and Tanahun respectively $(p<0.01)$. Hence it was clear that farmers of Tanahun are in better position for food sufficiency status as compared to those of Arghakhanchi.

\section{SUMMARY AND CONCLUSION}

The study revealed following facts:

1. More number of livestock can be raised if terrace farming system is practiced as compared to unterraced (Pata) farming system.

2. There is directly proportionate increase in terrace areas if terrace farming system is practiced, which can support the livestock feeding.

3. Although the terrace farming system has caused around $25 \%$ loss in cultivable land (Giri, 2012), there is no negative effects in the productivity of crops when compared to areas where this system is not present like in Arghakhanchi district. Famers of Arghakhanchi consider that terrace farming system reduces the yield due to land loss. Although loss of land in terraced farming system is true, but it has no negative effect in crop yield perhaps it might be due to 
conservation soil nutrients in terraced faring system. Farmers of Arghakhanchi are oblivious of several benefits of terraced farming system.

4. More number of fodder trees per unit land can be grown in terraced farming system as compared to unterraced (Pata) farming system and increased numbers of fodder trees have no negative effect in productivity of crops.

5. The application of chemical fertilizer rate is far greater where unterraced (Pata) farming system is in practice as compared to areas where terraced farming system is adopted. The increased use of chemical fertilizer in Arghakhanchi might be due to loss of nutrients and moisture from sloping land and less yield of farm yard manure resulting from less number of livestock holding.

6. The dry matter production per unit land to feed livestock from terraced farming system of Tanahun is greater than the unterraced (Pata) farming system of Arghakhanchi. Hence more number of livestock could be raised under unit land holding in terraced farming system as compared to unterraced (Pata) farming system.

7. The land which has steeper slope can also be brought into cultivation in terraced farming system as compared to unterraced (Pata) farming system, that is why the farmers of Tanahun has less area of uncultivable rainfed upland (Kharbari) holding.

8. The feed sufficiency status is better in terraced farming system as compared to unterraced (Pata) farming system. It might be due to increased yield of crops in terraced farming system due to conservation of soil nutrients and moisture as well as increased application or FYM resulted from greater number of livestock holding. Land with steeper slope can also be brought under cultivation in terraced farming system so that it has resulted more grain yield per unit land holding.

9. The availability of livestock feed is better in terraced farming system (despite the more number of livestock holding) as compared to unterraced farming system like in Arghakhanchi.

10. The contribution of fodder trees to the total dry matter production is greater in terraced farming system as compared to unterraced (Pata) farming system.

\section{REFERENCES}

Acharya, G.P., Tripathi, B.P., Gardner, R.M, Mawdesley KJ, Mc Donald MA. 2008. Sustainability of sloping land cultivation systems in the Mid-hill of Nepal. Land Degradation and Development 19:530-541.

Amatya, S.M., 1990. Fodder trees and their lopping cycle in Nepal. 2nd ed. Kathmandu: B.M. Amatya

ADB [Asian Development Bank]. 2001. Nepal Livestock Sector Review. Manila, Philippines.

Barakoti, T.P., 2004. Need of viable agro-forestry model with an example of terrace riser based agri-silvopastoral system in ARS [Agriculture Research Station] Pakhribas. National Workshop on Agro-forestry Proceedings, 2004. Kathmandu, Nepal: Nepal Agroforestry Foundation.

Giri, G., 2012. A comparative study of sloping unterraced (Pata) and terraced farming system on grain yield and animal feed availability in two hilly districts of Nepal. M.Sc dissertation submitted to Institute of Agriculture and Animal Science, Tribhuvan University, Nepal. 
Giri, M.K., 1990. Fodder production in Nepal - A review. In: Gatenby RM, Thapa B, Shrestha NP editors. Second Livestock Workshop Proceedings. Dhankuta, Nepal: Pakhribas Agricultural Center.

Malla, Y.B.,1980. Studies on the productivity of exotic grasses grown on terrace banks at Pakhribas Agricultural Centre. PAC [Pakhribas Agriculture Center] Technical Paper 48. Dhankuta, Nepal: PAC, pp 1-11.

MOAC [Ministry of Agriculture \& Cooperatives]. 2010. Agriculture Diary 2010. Harihar Bhawan, Nepal: MOAC.

NPC [National Planning Commistion]. 2007. Three Year Interim Plan 2007-2010. Kathmandu, Nepal: NPC.

Pande, R.S., 1994. Livestock Feeds and Grassland Development in Nepal. Kathmandu, Nepal: National Forage and Grassland Research Center.

Pariyar, D., 1993. Existing feed situation in different regions of Nepal and strategies developed to increase fodder production. International Symposium on Grassland Resources Proceedings. 1993. Beijing, China: Agricultural Science and Technology Press.

Siebert, S.F. and J.M. Belsky, 1990. Bench terracing in the Kerinci uplands of Sumatra, Indonesia. Soil and Water Conservation 45 (5):559-562.

Subba, D.B., 1998. Chemical composition and nutritive values of feed of East Nepal. Dhankuta: Pakharibast Agricultural center.

Tulachan, P.M.and A. Neupane, 1999. Livestock in mixed farming system of Hindu KushHimalayas,trends and sustainability. Kathmandu, Nepal: International Center for Integrated Mountain Development.

Upreti, C.R. and B.K. Shrestha, 2006. Nutrient contents of feed and fodder in Nepal. Kathmandu: National Agriculture Research Council. 